\title{
Moderasi Beragama di Kalangan Milenial Peluang, Tantangan, Kompleksitas dan Tawaran Solusi
}

\author{
Inayatillah \\ Sekolah Tinggi Agama Islam Negeri Tengku Dirundeng Meulaboh, Aceh \\ E-mail: inayatillah@staindirundeng.ac.id
}

\begin{abstract}
Abstact
The religious moderation campaign for millennial faces many challenges. The facts on the ground show that the phenomenon of radicalism is deeply rooted. The moderation program offered by the government has lost its reputation with the radicalism movement which is packaged attractively and in accordance with current trends. Through a qualitative approach and a radical paradigm of humanism, this study then tries to explore the root cause of the strengthening of radicalism and how complexities are faced by the discourse of religious moderation. This study then found several conclusions including, First, the moderation movement has been less fast and less attractive to millennial compared to the opposite movement. Second, the geneological roots of moderation and radicalism are not finished and are related to the relationship between religion and the post-independence state. Third, the influence of transnational radicalism. Fourth, socio-political-economic factors, including poverty, state violence, legal injustice, political instability, racial issues, militarism and so on. The only opportunity that the discourse of religious moderation has is the preindependence cultural roots, through strengthening cultural values, Islamic treasures (intellectual Islam) and the welfare economic movement. If such opportunities are not utilized, the movement and discourse of religious moderation will run aground in the middle of the road.
\end{abstract}

Keywords: Religious Moderation, Millennials, Islam, radical humanism

Abstrak
Kampanye moderasi beragama bagi milenial menghadapi banyak
tantangan. Fakta lapangan mengemukakan fenomena radikalisme telah
mengakar kuat. Program moderasi yang ditawarkan pemerintah kalah
pamor dengan gerakan radikalisme yang dikemas menarik dan sesuai
dengan trend kekinian. Melalui pendekatan kualitatif dan paradigma
radikal humanisme, penelitian ini kemudian mencoba menggali akar
masalah dari penguatan radikalisme dan bagaimana kompleksitas yang


dihadapi oleh wacana moderasi beragama. Penelitian ini kemudian menemukan beberapa simpulan diantaranya, Pertama, gerakan moderasi telah kalah cepat dan kalah menarik bagi kalangan milenial dibandingkan dengan gerakan yang berlawanan. Kedua, akar geneologi moderasi dan radikalisme yang tidak selesai dan berkaitan dengan hubungan antara agama dan negara pasca kemerdekaan. Ketiga, pengaruh radikalisme transnasional. Keempat, faktor sosial-politikekonomi, meliputi kemiskinan, kekerasan negara, ketidakadilan hukum, ketidakstabilan politik, isu sara, militerisme dan lain sebagainya. Satusatunya, peluang yang dimiliki oleh wacana moderasi beragama hanyalah akar kultural pra kemerdekaan, melalui penguatan nilai budaya, khazanah keislaman (islam intelektual) dan gerakan ekonomi kesejahteraan. Jika peluang demikian tidak dimanfaatkan, maka gerakan dan wacana moderasi beragama akan kandas di tengah jalan.

Kata Kunci: Moderasi Beragama, Millenial, Islam, radikal humanisme

\section{PENDAHULUAN}

Menurut proyeksi BPS tahun 2019, 48,62 persen atau hampir setengah penduduk Indonesia berusia antara 14-35 tahun. Pada tahun 2020 Asosiasi Penyelenggara Jasa Internet Indonesia (APJII) bekerjasama dengan Indonesia Survey Center memproyeksikan angka yang lebih mencengangkan bahwa penduduk Indonesia pada usia yang sama mencapai 62,4 persen. Artinya ada potensi SDM yang cukup besar untuk menyongsong Indonesia baru di masa depan, dimana sebagian besar dari penduduk Indonesia berada pada usia yang cukup produktif dan dekat dengan internet. (APJII, 2020).

Lembaga yang sama juga mencatat bahwa penetrasi pengguna internet tahun 2019-2020 adalah 196.71 juta jiwa dari 266.91 juta jiwa penduduk Indonesia atau dengan kata lain $73,7 \%$ penduduk Indonesia adalah pengguna internet. Keterhubungan melalui dekstop (9.5\%) Laptop (19.7\%) Gadget (95.4 \%) dengan penggunaan 8 jam ke atas mencapai 19,5 persen. Sedangkan alasan utama penggunaan internet adalah sosial media dan komunikasi. Sedangkan alasan lainnya yaitu untuk mengakses layanan publik, belanja online, games dan hiburan (APJII, 2020)

Kedekatan dengan internet dan media sosial menjadikan generasi milenial memperoleh limpahan informasi yang terkadang jika tidak memiliki filter yang baik akan membawa kepada dampak yang buruk. Salah satu faktor negatif yang menimpa generasi milenial adalah mudahnya mereka disusupi doktrin-doktrin transnasional berfaham radikal. 
Kenyataannya, gerakan radikalisme fundamental Islam abad ke 21 di Asia dan Timur Tengah menyadari keefektifan internet sebagai media penyebar ideologi yang mereka usung. John L. Esposito, dkk menyebutkan bahwa penyebaran ide-ide politik dan isu kebebasan ekspresi dan isu demokrasi ditenggarai mengalami radikalisasi secara massif karena dipengaruhi oleh media internet (John L. Esposito, et.al, ed, 2008:267) Dengan kata lain, isu-isu fundamentalisme yang mengarah kepada radikalisme di Abad 21 erat kaitannya dengan penggunaan yang massif atas internet dan media sosial.

Selain itu, kita juga terlambat menyadari bahwa melalui internet, radikalisme telah begitu menyebar dan mengakar dalam benak generasi milenial bangsa khususnya mahasiswa. Internet memiliki faktor signifikan dalam pembentukan elemen radikalisme di kalangan anak-anak muda. Hal itu dikuatkan dengan hasil temuan Pusat Studi Budaya dan Perubahan Sosial Universitas Muhammadiyah (Tempo, 2017), dimana situs-situs yang terindikasi menyebarkan hoax dan kebencian menempati urutan teratas ketimbang situs yang dimiliki oleh Muhammadiyah dan NU. Kekhawatiran ini semakin menguat atas informasi yang dipaparkan oleh Badan Nasional Penanggulangan Terorisme (BNPT), yang menyebutkan bahwa 52\% yang menjadi napi terorisme dalam LP tersebut adalah anak-anak muda (Alius, 2017). Maka tak mengherankan, jika milenial menjadi kelompok yang rawan terpapar radikalisme. Ditambah lagi, moderasi beragama sebagai nilai yang harus dijunjung dalam masyarakat plural seperti Indonesia semakin terkikis diserbu oleh ideologi Islam transnasional yang disatu sisi menampilkan penguatan simbol dan identitas dan sisi lain melakukan kritik terhadap negara bangsa dan tradisi keislaman di nusantara.

Riset Setara Institut tahun 2019 memperlihatkan bahwa paradigma keagamaan mahasiswa di berbagai perguruan tinggi negeri telah dikuasai oleh kelompok-kelompok fundamental seperti Hizbut Tahrir dan berbagai transformasinya adalah aktivitas gerakan tarbiyah. Beberapa perguruan tinggi yang menjadi objek riset yaitu UI, ITB, IPB dan UIN Syarif Hidayatullah Jakarta. Riset ini menyimpulkan tiga wacana dominan yang secara nyata jauh dari semangat moderasi yaitu Pertama terkait kewajiban menjalankan ajaran dan nilai Islam dalam kehidupan bermasyarakat. Kedua, posisi Islam yang senantiasa terancam karena diserang dari berbagai lini. Akibatnya dikembangkan ide persatuan politik Islam, bahwa Islam hanya akan mencapai kejayaan bila umat Islam bersatu dalam struktur pemerintahan dan politik dalam (yang menurut 
dugaan mereka) sistem perpolitikan Islam. Ketiga, penaklukan Barat atas Islam diyakini karena penguasaan pemikiran dan kebudayaan sehingga berimbas kepada sikap mereka yang eksklusif, penuh curiga, memusuhi dan menutup diri (Babun Suharto et.al, 3:2019)

Pemerintah kemudian menyadari bahaya jangka panjang dari fundamentalisme dan doktrin faham radikal. Untuk itu, pada peraturan presiden nomor 18 Tahun 2020 tentang rencana pembangunan Jangka Menengah Nasional (RPJMN) Tahun 2020-2024, moderasi beragama menjadi salah satu isu strategis. Namun, berbagai strategi dan langkah yang dilakukan nyatanya belum menampakan hasil yang memuaskan. Disatu sisi isu moderasi beragama mengarah kepada sektarian ormas tertentu dan disisi lain ia menjadi semacam bamper anti-kritik dari pemerintah terhadap wacana-wacana kritis berkenaan dengan isu ketidakadilan dan ketimpangan sosial ekonomi. Disisi lain yang lebih jauh narasi dan panggung milenial masih dikuasai oleh orang-orang yang beragama secara eksklusif.

Ketidaktuntasan persoalan moderasi beragama juga diperparah oleh pembacaan terhadap situasi yang tidak menyeluruh dan mengakar. Milenial ingin dimoderasi tapi mereka diposisikan secara pasif. Padahal dalam kehidupan milenial terdapat dinamika dan kompleksitas yang tinggi. Milenial hidup di dunia yang jauh lebih luas dari dunia yang pernah dimasuki oleh generasi tua. Mereka mengalami keterlimpahan informasi yang jika tidak memiliki filter yang kuat akan membawa kepada dampak yang serius.

Target utama tulisan ini adalah membuka perspektif secara lebih luas dan lebih kritis terkait wacana moderasi beragama dikalangan milenial. Untuk itu, disini pertama akan dilakukan pembacaan dan pemetaan masalah berkenaan dengan isu moderasi beragama di kalangan milenial, meliputi peluang, tantangan dan kompleksitas. Kedua, menawarkan solusi berbasis akar masalah dan sekaligus signifikansi peran perguruan tinggi keagamaan Islam (PTKI) melalui program tridharma perguruan tinggi.

Pembacaan peluang menjadi penting untuk mengetahui visi dari moderasi beragama bagi pengembangan generasi milenial. Moderasi beragama tanpa visi eksistensi terkesan hanya memaksakan satu perspektif. Eksplorasi peluang menjadi penting untuk menentukan tujuan-tujuan yang ingin dicapai dalam moderasi beragama dikalangan milenial. 
Moderasi beragama serumit apapun sejatinya memiliki peluang untuk berkembang ditengah-tengah generasi milenial. Sikap moderat dalam beragama dapat membantu generasi milenial memperoleh kesempatan berkarya yang lebih tinggi. Sikap moderat membuka peluang kontak dan interaksi dengan entitas di luar sehingga kesempatan untuk mengembangkan diri menjadi lebih terbuka.

Banyak generasi muda yang hancur masa depannya ketika salah memilih jalan. Mereka terjebak dalam sikap radikal, eksklusif, membuat diri tidak berkembang dan hilangnya berbagai kesempatan untuk mendapatkan kehidupan yang layak dan damai sejahtera. Generasi milenial yang demikian hanya akan menjadi masalah bagi dunia di sepuluh, duapuluh atau tigapuluh tahun ke depan.

Begitupun pembacaan tantangan menjadi perlu untuk mengetahui tantangan apa saja yang dihadapi. Setidaknya dalam penawaran wacana moderasi diketahui hambatan yang mungkin akan dihadapi dan segala rintangan dilapangan. Tujuannya supaya ada antisipasi, kesadaran dan kewaspadaan bagi para pemangku bahwa sosialisasi moderasi beragama dapat saja mengalami jalan buntu.

Hari ini, wacana moderasi beragama telah datang terlambat. Kaum muda telah begitu mengakrabkan diri dengan narasi-narasi ekstrim dan radikal. Kesadaran bahwa wacana ini datang di waktu yang tidak tepat, dan tantangan bahwa ekstrimisme dan radikalisme telah sampai pada fase mapan di benakbenak kaum milenial, membuat pemangku dan kita mau menginstrospeksi diri. Dengan menyadari tantangan tersebut, kita dapat memastikan bahwa langkahlangkah yang dipilih dalam mewacanakan moderasi beragama dikalangan milenial tepat sasaran.

Begitupun pembacaan terhadap kompleksitas adalah untuk mengurai paradoks-paradoks dalam persoalan ini. Misalnya disatu satu sisi, pemerintah menawarkan moderasi beragama, tapi disisi lain ia menjadi semacam proyek politik populis untuk kepentingan penguatan identitas kelompok tertentu. Contoh lain misalnya ketika disatu sisi moderasi beragama mensyaratkan penerimaan terhadap tradisi, tapi disisi lain tidak semua tradisi sejalan dengan nilai agama yang dianut oleh masyarakat Indonesia. Pluralitas masalah, pemahaman keagamaan dan batasan nilai yang terdapat dalam tradisi juga harus dikaji secara utuh, sehingga penguatan dimensi agama tidak mengorbankan dimensi tradisi begitupun sebaliknya. 
Dalam paradigma sosial, semua aspek tidak dapat ditinjau dari hitam dan putih. Moderasi beragama adalah berbeda bagi setiap pemahaman, begitupun ekstrimisme dan radikalisme punya tingkatan tersendiri. Kesadaran graduasi kebenaran dan pemahaman dapat membantu upaya-upaya moderasi yang lebih kontekstual dan personal.

Terakhir tawaran berbasis masalah, tentang bagaimana pemerintah, tokoh masyarakat, ulama, akademisi, intelektual dan masyarakat secara umum harus terlibat secara bahu membahu membangun diskursus tafsir moderat dalam agama dan mensosialisasikannya. Melalui kerjasama semua pihak diharapkan moderasi beragama dapat terimplementasi dalam benak, jiwa dan sikap seluruh masyarakat Indonesia. Selain itu, dalam bagian ini juga akan dipaparkan peran PTKI dalam reproduksi, sosialisasi dan implementasi program-program tridharma berbasis moderasi beragama Dimana tawaran dari PTKI dapat menjadi sangat komprehensif menyesuaikan dengan akar masalah mulai dari reproduksi tafsir, diskursus, sosialisasi hingga kepada pendampingan sosial ekonomi.

\section{METODE PENELITIAN}

Metode yang digunakan dalam penelitian ini adalah metode kualitatif dengan cara melakukan kritik paradigma atas fenomena dalam hal ini paradigma yang dikritik adalah moderasi beragama. Lebih tepatnya penelitian ini menggunakan paradigma radikal humanism yang memandang bahwa perubahan dapat dilakukan melalui penyadaran (consciousment) dan pencerahan (enlightenment). Sesuai namanya, paradigma humanis radikal merupakan kombinasi antara aspek radikal dan subjektifitas manusia. Sifatnya yang kritis lebih berusaha untuk melihat satu fenomena secara praktis, anti-positifistik dan ideologis. Ia dapat juga merupakan lawan atau kritik dari asumsi yang didefinisikan oleh paradigm fungsional.

Paradigma humanis radikal didefinisikan oleh kepeduliannya untuk mengembangkan sosiologi perubahan radikal dari sudut pandang subjektivis. Pendekatannya terhadap ilmu sosial memiliki banyak kesamaan dengan paradigma interpretatif, dalam hal memandang dunia sosial dari perspektif yang cenderung nominalis, anti-positivis, voluntarist dan ideografis. Dengan demikian, orientasi yang paling utama disini adalah kemampuan tawaran kritis terhadap satu fenomena yang dianggap mapan, seperti moderasi beragama 
ketika dihadapkan kepada generasi milenial. Salah satu gagasan paling mendasar yang mendasari keseluruhan paradigma ini adalah bahwa kesadaran manusia didominasi oleh suprastruktur ideologis yang dengannya ia berinteraksi, dan bahwa ini mendorong irisan kognitif antara dirinya dan kesadaran sejatinya. Irisan ini adalah irisan 'keterasingan' atau 'kesadaran palsu', yang menghambat atau menghalangi pemenuhan manusia sejati. Perhatian utama disini adalah melepaskan manusia dari kendala-kendala regulasi dan kritiknya terhadap status quo. Disini semua ikatan-ikatan yang telah mapan dilampaui untuk menemukan potensi seutuhnya dari manusia (Gibson Burrel dan Gareth Morgan, 2005:32).

Dalam kasus moderasi beragama, wacana tersebut akan dilihat secara kritis dengan mengesampingkan status quo. Kebijakan dan tawaran moderasi beragama dari pemerintah kemudian juga ditanggapi secara kritis untuk menemukan titik lemah dari wacana tersebut. Dengan demikian, diharapkan penelitian ini juga akan memberi kontribusi bagi penguatan gagasan dan implementasi moderasi beragama yang menjadi salah satu program unggulan pemerintah.

\section{HASIL DAN PEMBAHASAN}

\section{Moderasi Beragama: Peluang, Tantangan dan Kompleksitas}

Secara kultural, moderasi beragama diakui merupakan ruh dan model keagamaan yang berkembang secara beradab-abad di Nusantara. Masyarakat nusantara yang pluralistik tapi sangat religious mampu menjadi role model bagi pengembangan toleransi dan inklusifisme. Nilai, prinsip dan praktik keagamaan di Nusantara didasarkan pada konsep tasammuh dalam agama, tidak ekstrim kiri (radikal fundamental) dan tidak pula ekstrim kanan (liberal sekuler).

Islam kultural yang dikembangkan oleh pesantren misalnya memiliki konstruksi pemikiran yang adaptif, toleran dan inklusif. Namun hari ini, pandangan tersebut mendapat tantangan dan ancaman dari kemunculan berbagai ideologi dan pemahaman keagamaan yang baru. Pandangan baru tersebut berupa kecenderungan pada sikap intoleran, ekstrim dan radikal. Beberapa kelompok Islam yang memiliki kecenderungan pada sikap radikal dan militan mulai melakukan perlawanan dengan meneriakkan penegakan syariat Islam dan pendirian negara Islam. Beberapa kelompok tersebut seperti Hizbut 
Tahrir Indonesia (HTI), Laskar Jihad (LJ), Majelis Muhajidin Indonesia (MMI) dan Jama'ah Islamiyah (Ali Muhtarom et.al,2020:4).

Sementara itu, menurut Quraisy Shihab, sikap moderat diartikan sebagai keberadaan ditengah tapi tetap dalam lingkung tarik menarik di kedua sisi. Moderasi bukan duduk stagnan ditengah tapi terlibat secara aktif menyeimbangkan arus kiri dan kanan, sehingga menuntut kesabaran dan keuletan dalam menghadapinya, melainkan juga membutuhkan pengetahuan dan pemahaman yang memadai, sehingga tidak terseret oleh salah satu ujungnya. Justru sebaliknya, kedua ujung di sisi harus ditarik ke tengah dalam rangka mencapai keadilan dan kebaikan yang merupakan syarat mutlak terciptanya moderasi (Quraisy Shihab, 2019:03)

Jika merujuk kepada pernyataan Quraisy Shihab tersebut, jelas bahwa moderasi beragama bukanlah posisi stagnan tetapi merupakan karakter dinamis yang aktif. Seorang moderat dalam keagamaannya berusaha merangkul kedua sisi dan tidak melepaskannya begitu saja. Moderasi juga merupakan sintesis dari dua premis yang saling berlawanan. Beragama secara moderat adalah model keberagamaan yang sesuai dengan spirit, ajaran dan nilai Islam.

Moderasi beragama sendiri dalam Keputusan Dirjen Pendidikan Islam Nomor 897 Tahun 2021 Tentang Petunjuk Teknis Rumah Moderasi Beragama didefenisikan sebagai cara pandang, sikap, dan praktik beragama dalam kehidupan bersama dengan cara mengejawantahkan esensi ajaran agama yang melindungi martabat kemanusiaan dan membangun kemaslahatan umum, berlandaskan prinsip adil, berimbang, dan menaati konstitusi sebagai kesepakatan berbangsa. (Dirjen Pendis, 2021)

Moderasi beragama juga berkaitan dengan paradigma, sikap dan tingkah laku keagamaan yang mengambil spirit maqasid syari'ah yaitu melindungi martabat kemanusiaan dan kebaikan bersama. Prinsip yang diambil adalah keadilan, keberimbangan dan konstitusi. Dalam hal ini, moderasi beragama diyakini sebagai perluasan konsep maqasid syari'ah. Jaser Auda seperti yang ditulis oleh Zaprulkhan meluaskan konsep maqasid syari'ah misalnya pada aspek hifz al din, difahami sebagai penghormatan terhadap kebebasan memeluk agama yang diyakini dan beribadah menurut agamanya. Konsep ini menjadi jaminan kerukunan kehidupan beragama yang sehat dan harmonis karena kebebasan berkeyakinan tanpa paksaan merupakan salah satu sendi ajaran Islam (Zaprulkhan, 2020:329) 
Spirit maqasid syari'ah juga dapat diadopsi melalui penguatan dan internalisasi terhadap pemahaman keagamaan. Maqasid syari'ah adalah falsafah dan instrumen paradigmatik dari wacana moderasi beragama yang digunakan di Indonesia dan dimanapun. Karena keluasan cakupan, kedinamisan dan ketepatan dimensi yang dimiliki untuk mencapai kemaslahatan di dunia dan di akhirat. Keluasan cakupan, kedinamisan dan ketepatan sudut pandang juga berguna dalam kerangka menghadapi radikalisme dan ekstrimisme beragama yang juga sangat kompleks.

Negara juga menetapkan beberapa indikator moderasi beragama yaitu komitmen kebangsaan, toleransi dan anti-kekerasan serta penerimaan terhadap tradisi. Komitmen kebangsaan dituntut sebagai konsekwensi kehidupan berbangsa dan bernegara dimana setiap warga negara Indonesia harus menerima prinsipprinsip bernegara berdasarkan Pancasila, Undang-Undang Dasar Negara Republik Indonesia dan regulasi-regulasi yang diturunkan darinya. Penerimaan terhadap Pancasila dan Undang-Undang Dasar Negara Republik Indonesia diyakini adalah bagian dari sikap keberagamaan itu sendiri (Dirjen Pendis, 2021).

Sedangkan toleransi memiliki beberapa indikator penting diantaranya semangat menghormati perbedaan (keyakinan termasuk perbedaan pandangan dan pendapat). Dalam aspek keyakinan, toleransi berarti memberi ruang bagi orang lain untuk berkeyakinan dan mengekspresikan keyakinannya. Dalam aspek pandangan, toleransi harus berwujud dari sikap kesetaraan bahwa sebagai warga negara Indonesia, kita memiliki kesetaraan sosial dan hukum. Negara tidak melebihkan satu pemeluk agama dari yang lain. Warga negara-pun tidak menganggap dia sebagai warga negara istimewa dan yang lain sebagai warga negara kelas dua. Setiap warga negara memiliki hak kesetaraan dan kesejahteraan yang sama sebagaimana termaktub dalam undang-undang dasar 1945. Dalam aspek pendapat dan kesediaan bekerjasama, setiap warganegara berhak memberikan kontribusi yang sama bagi pembangunan Indonesia seperti mengikuti pemilu dan menyampaikan aspirasi. Hal ini sejalan dengan nilai gotong-royong yang dianut oleh bangsa Indonesia, bahwa antar umat beragama harus ada kerjasama dalam kerangka pembangunan nasional. Hal ini dapat terwujud jika diantara warga negara telah dibangun prinsip kesamaan dan kesetaraan.

Kesemua nilai yang menjadi indikator bagi moderasi beragama tersebut berkaitan erat dengan persoalan-persoalan yang dihadapi oleh bangsa Indonesia 
yaitu isu kebangsaan (yang melahirkan radikalisme politik), isu toleransi (melahirkan radikalisme teologi), isu anti-kekerasan (melahirkan radikalisme kemanusiaan) dan isu penerimaan terhadap tradisi (yang melahirkan radikalisme fundamentalisme dan puritanisme). Isu-isu tersebut berimbas pada ancaman terhadap stabilitas nasional, merusak keharmonisan antar umat, menyuburkan sentimen identitas dan memunculkan efek ketidakstabilan politik, ekonomi, sosial dan keamanan.

Tindakan kekerasan massa, terorisme dan kejahatan media yang ditenggarai oleh radikalisme beragama telah sampai pada titik yang mengkhawatirkan. Orang-orang mudah dihasut untuk berbalik melawan negara dan menolak negara bangsa. Masyarakat juga lebih mudah disusupi hoak dan dipolitisir dengan menggunakan isu agama. Untuk itu, perlu ada pemetaan yang menyeluruh dan mendalam untuk sampai kepada solusi dan alternatif.

Untuk itu, penguatan moderasi beragama dikalangan milenial harus didasari oleh aspek peluang, tantangan dan kompleksitas. Peluang tersebut meliputi potensi milenial sebagai mercusuar bagi pengembangan semangat moderasi beragama di masa yang akan datang. Tantangan yang dihadapi adalah ketika arus radikalisasi lebih kuat daripada arus moderasi itu sendiri. Penguatan ini memiliki faktor islamo-politik yang mengakar jauh ke belakang sejarah bangsa, dan mengalami pengerasan dari gerakan lokal menuju fundamentalisme global yang tersebar melalui internet. Adapun kompleksitas berkenaan dengan potensi radikalisme yang dimiliki oleh semua agama dan kepercayaan. Klaim kebenaran tunggal mempersulit sosialisasi moderasi beragama. Reinterprestasi teks untuk menyesuaikan dengan konteks global sangat dibutuhkan.

Berikut ini empat indikator moderasi agama versi pemerintah yakni komitmen kebangsaan, toleransi, anti kekerasan dan penerimaan terhadap tradisi, maka

\section{Komitmen Kebangsaan}

Salah satu indikator dalam penguatan moderasi beragama di Indonesia adalah komitmen kebangsaan. Penempatan komitmen kebangsaan dalam narasi moderasi beragama di Indonesia bertujuan untuk mencapai stabilitas (maslahah) kebangsaan yang sesuai dengan semangat maqasid syari'ah untuk mencapai kemaslahatan umum.

Peluang moderasi beragama dikalangan milenial dapat menjadi penjaga pertama komitmen kebangsaan dari rongrongan politik dan ideologi dari dalam 
dan luar negeri (yang lebih sering merupakan imbas dari ekonomi/ politik ekonomi). Milenial dapat menjadi pelopor pembaharuan paradigma dan definisi komitmen kebangsaan sehingga tidak rigit, terkesan pro-rezim dan anti-kritik.

Tantangan adanya faham milenial bahwa Islam dan negara bangsa adalah dua hal yang terpisah. Sebagian dari mereka telah mendapatkan doktrin bahwa model negara bangsa bukan merupakan model bernegara secara Islami. Disatu sisi milenial melihat ketimpangan dan ketidakadilan dan disisi lain mereka menemukan "alternatif" yang ditawarkan, walaupun alternatif tersebut basisnya juga sesuatu yang mengambang, bukan rasional apalagi faktual. Ketika generasi muda merasakan iklim demokrasi hanya melahirkan pemimpin yang korup, maka mereka mendapatkan alternatif "khalifah" yang ditawarkan secara teologis, take for granted, walaupun sistem itu sendiri belum diuji dalam iklim demokrasi.

Selain itu, kompleksitas yang dihadapi adalah kenyataan bahwa bangsa dan kebangsaan adalah proses alamiyah. Ada polemik yang mencuat. Tuntutan komitmen kebangsaan tidak sejalan dengan prilaku yang dipertontonkan elit politik yang korup dan hedonis (Bustamam-Ahmad, K., 2019). Komitmen kebangsaan menjadi sesuatu yang beku dan over control dari pemerintah sehingga alih-alih mengapresiasi, milenial justru menganggap diskursus menuju komitmen kebangsaan yang dinamis yang ditawarkan oleh pemerintah hanyalah upaya-upaya melanggengkan kekuasaan dan anti-kritik.

\section{Toleransi}

Milenial memiliki peluang untuk menjadi pelopor bertoleransi dalam berbagai hal dan konteks, khususnya dalam menyampaikan pendapat, mengawal kebebasan berkeyakinan dan menjalankan keyakinan. Generasi milenial adalah generasi yang hidup di era globalisasi dimana baik secara langsung maupun tidak langsung, kontak dengan orang-orang yang berbeda secara kultur dan keyakinan adalah sesuatu yang tidak dapat dihindarkan. Generasi milenial saat ini memiliki peluang untuk berkolaborasi, bersaing dan menciptakan kemajuan bersama orang-orang dari berbagai belahan dunia dengan latar belakang yang berbeda (Ilyas, at al., 2020). Disatu sisi, sikap inklusif dan terbuka sangat dibutuhkan.

Disisi lain, sikap eksklusif hanya akan membuat kemunduran dan menjadikan milenial mandek, tidak bisa berkembang dan tidak memperoleh 
kesempatan yang lebih luas untuk mengembangkan diri dan berkolaborasi. Generasi muda yang toleran adalah modal untuk memajukan bangsa melalui kolaborasi dan kerjasama lintas etnis dan agama untuk memajukan pembangunan.

Nilai toleransi sebenarnya menjadi bagian penting dalam perjalanan Islam membangun harmoni. Toleransi sesungguhnya adalah kesediaan para pihak untuk saling mengerti dan memberi pengakuan (Nasruddin Umar, 2019:37). Namun sayangnya, tantangan muncul dalam bentuk radikalisasi akibat pengaruh media massa. Sebagian generasi milenial mengandrungi dakwah penuh hasutan kebencian, sehingga lahir paradigma yang keliru bahwa keimanan diukur dari seberapa kebencian terhadap yang berbeda. Dakwahdakwah radikal menjadi favorit dikalangan milenial karena ada proses pembentukan dan penguatan identitas (eksistensi) sehingga mereka tidak malu untuk menampilkan identitas keagamaan dan mengekspresikan kebencian kepada yang berbeda.

Kompleksitas yang terjadi adalah ketika diskursus teologi perihal agama yang benar, yang belum difahami secara matang oleh generasi milenial. Sebagian milenial meyakini bahwa penguatan simbol-simbol keagamaan, intoleransi dan ekspresi kebencian terhadap the other adalah bagian dari ajaran agama itu sendiri.

Kompleksitas terbesar dari isu toleransi adalah kedangkalan pemahaman keagamaan. Dalam pemahaman keagamaan yang ekstrim, toleransi difahami sebagai kompromi akidah. Ekspresi kebencian dan sikap intoleran dianggap merupakan representasi Islam kaffah.

Yang kita hadapi hari ini, dakwah radikal lebih masif menyasar generasi milenial dengan tampilan dan propaganda yang lebih memukau. Sedangkan dakwah toleransi yang digaungkan oleh arus-utama Islam di Indonesia belum menampilkan model dakwah toleran yang menarik. Ada kecenderungan sikap pasif dari Islam arus utama sehingga abai dalam melihat bahaya dan potensi radikalisme di kalangan milenial mereka sendiri.

\section{Anti-Kekerasan}

Milenial memiliki peluang untuk menjadi pelopor dalam menolak segala model kekerasan baik kekerasan kognitif, kekerasan emosional dan fisik. Persentuhan lintas etnik dan agama dapat menggerakkan paradigma 
humanisme dan penghormatan terhadap hak-hak asasi manusia (BustamamAhmad, K., 2019). Milenial lahir dari iklim modern dimana etika kemanusiaan adalah tuntutan tersendiri yang harus dikembangkan untuk kemajuan dan eksistensi.

Namun sayangnya, tantangan muncul ketika milenial memahami konsep-konsep beragama secara keliru. Misalnya dalam memaknai jihad mereka mengaktualisasikan ajaran tersebut dalam bentuk kekerasan dan atas nama nahi munkar. Penanaman teologi kekerasan membawa image bahwa agama tidak mau tidak harus ditegakkan dengan pedang (kekerasan). Padahal, agama lahir sebagai rahmat dan dakwah agama harus mengedepankan aspek-aspek rahmat bagi semesta alam.

Kehadiran sikap dan pemahaman demikian tidak lepas dari, fenomena sosial, politik dan ekonomi. Ketidakadilan, ketimpangan ekonomi, lemahnya hukum ditenggarai memunculkan ketidakpuasan dikalangan milenial. Faktor politik ekonomi, memperuncing isu identitas yang juga dapat menyebabkan kekerasan. Generasi muda milenial mudah diajak dan diarahkan etika dipancing dengan ketidakadilan dan ketimpangan ekonomi.

Praktik kekerasan, perundungan, perampasan dan razia ilegal yang dilakukan oleh ormas, walaupun dikesankan sebagai perbuatan nahi munkar, tapi memiliki motif politik ekonomi yang tersembunyi. Berupa sentimen ketimpangan ekonomi, perebutan sumber daya dan alat-alat produksi serta persaingan kapitalisme.

Kita dapat melihat kekerasan yang dipelopori oleh ormas-ormas radikal agama kepada orang-orang yang dianggap melanggar syari'at dan menistakan agama. Pelakunya jelas lebih banyak dari kalangan generasi milenial. Mereka adalah orang-orang yang mencari jati diri, mencoba bereksistensi dan meraih kebermaknaan hidup tapi dengan jalan yang salah, yakni jalan kekerasan. Padahal kekerasan adalah tindakan yang jauh dari semangat agama yang rahmatan lil alamin. Agama mengedepankan kemanusiaan, dan kasih sayang.

Yusuf Al-Qardhawi memaparkan ciri-ciri kelompok radikal yaitu pertama, mengklaim kebenaran tunggal dan menyesatkan pandangan yang berbeda. Kedua, keras dalam ibadah ketika yang sunnah dianggap wajib dan makruh dianggap haram. Ketiga, kebanyakan mereka mengalami overdosis dalam beragama sehingga dalam berdakwah tidak mengenal graduasi dan proses (efek dari sikap ini adalah munculnya terorisme dan bunuh diri atas nama 
agama). Keempat, kasar dalam berinteraksi dan emosional dalam berdakwah. Kelima mudah berburuk sangka dan hanya melihat sisi negatif dari kelompok yang dianggap lawan. Keenam, mudah mengkafirkan orang yang berbeda pendapat (Babun Suharto, 2019:18).

Islam tidak pernah memperkenalkan politik mayoritas dan minoritas. Islam mengajarkan bahwa sekecil apapun satu kelompok tetap harus diperhatikan dan diperlakukan sama dengan kelompok yang lain sebagaimana hadis nabi yang diriwayatkan oleh Abu Daud bahwa siapa saja yang mendhalimi mu'ahad (minoritas) atau melecehkan mereka dan membebani mereka dengan sesuatu diluar kesanggupan mereka akan menjadi lawan bagi Nabi kelak di hari kiamat. Dalam hal ini Nabi menyatakan dengan tegas keberpihakannya terhadap semua kelompok tanpa membedakan jenis kelamin, kesukuan, agama dan ideologi/kepercayaan (Nasruddin Umar, 2019:19)

Menurut Franz Magnis Suseno, human dignity atau martabat manusia ada karena pemberian tuhan. Dalam pancasila, Sila pertama Ketuhanan Yang Maha Esa terkait erat dengan sila sesudahnya yaitu Kemanusiaan yang Adil dan beradab. Tak mungkin seseorang mengaku bertuhan apabila ia bersikap tidak adil dan tidak beradab. Begitupun sebaliknya, Kemanusiaan yang Adil dan Beradab harus diwujudkan secara nyata melalui kesejatian dalam pengakuan terhadap Ketuhanan Yang Maha Esa. Nilai rahmatan lil alamin harus dituntut dari segenap agama. Agama itu harus dirasakan sebagai rahmat oleh semua yang bersentuhan dengannya (Franz Magnis Suseno, 2015:07).

Dengan penguatan nilai-nilai ketuhanan dan kemanusiaan, kekerasan dalam beragama dapat dihindari. Walaupun agama memiliki potensi kekerasan, tapi inti dan substansi keagamaan adalah kedamaian dan penghormatan terhadap hak asasi manusia. Dalam hal ini, aspek kognitif menjadi penting dimana pengetahuan keagamaan diperdalam sehingga mendapatkan pemahaman keagamaan yang toleran dan tidak radikal.

\section{Penerimaan terhadap tradisi}

Pemuda dapat ikut serta mengembangkan tradisi yang telah ada dalam semangat, "Mempertahankan khazanah masa lalu yang baik dan mengambil khazanah masa kini yang lebih baik." Sehingga penerimaan terhadap tradisi bukan berarti menolak kebaruan, tapi lebih kepada pelestarian nilai-nilai kearifan sebagai khazanah bangsa. Pemuda dapat mengembangkan sikap dan pandangan mengenai tradisi yang baik sehingga sikap dan pandangan tersebut dapat 
menjadi sikap dan pandangan bersama kita dalam kehidupan berbangsa dan bernegara.

Adanya perang pemikiran yang secara gencar menekankan kepada prilaku salaf as shalih dan penolakan atas tradisi. Adanya meme-meme yang beredar yang menjadi bagian dari propaganda menolak tradisi. Beberapa waktu lalu ada propagada meme klepton (semacam panganan biasa) bukan Islam. Arabisasi yang dipropagandakan sebagai islamisasi telah mencampuradukkan antara substansi agama dan produk budaya. Akibatnya khazanah, budaya, tradisi, identitas lokal yang memiliki nilai tinggi terancam eksistensinya.Milenial yang tidak memahami tradisi dengan baik sebagai modal sosial dan ketahanan bangsa akan mudah terjerumus dalam radikalisme dan kekerasan.

Penolakan terhadap tradisi yang berkembang telah menjadi sedemikian masif. Propaganda yang gencar, sistematis, kreatif dan modern diserukan dari berbagai kanal sosial media dan mempengaruhi generasi muda. Ada keterlambatan antisipasi yang sangat signifikan ketika hari ini milenial sangat rentan terhadap faham-faham radikalisme yang menolak tradisi.

Islam tidak tepat jika dikonfrontasi dengan ajaran agama terdahulu karena kehadiran Islam adalah mengakomodir dan menghimpun nilai-nilai kebaikan dari generasi sebelumnya. Islam juga tidak dapat dipertentangkan dengan universal human right atau hak asasi manusia universal karena kebebasan dan hak asasi manusia adalah bagian dari Islam. Islam juga tidak dapat dibenturkan dengan khazanah dan nilai-nilai lokal karena konsep universalitas Islam dapat dibangun dan ditegakkan dari tradisi dan keunikan lokal (Nasruddin Umar, 2019:4)

Universalitas dalam ajaran Islam sebenarnya memberi ruang kepada nilai-nilai lokal dan tradisi untuk terus bertahan dan berkembang. Nusantara adalah contoh yang paling unik dimana Islam menjadi mayoritas sekaligus hadir dalam nuansa yang kaya, sekaya kearifan lokal yang terdapat didalamnya. Disatu sisi, meskipun mereka jauh dari tempat kelahiran Islam tapi kehidupan mereka tidak dapat dipisahkan dari ajaran-ajaran Islam sembari tetap menjaga tradisi dan budaya (Nasruddin Umar, 2019:12).

Nasaruddin Umar lebih jauh menetapkan asas-asas moderasi yang memuat unsur-unsur seperti, Pertama al-ikha' yaitu menjunjung tinggi rasa persaudaraan dan kemanusiaan. Kedua al-musawwa dimana Islam lebih mengedepankan pada prinsip persamaan dari perbedaan. Ketiga, tasammuh yaitu toleran terhadap yang berbeda. Keempat, musyawarah yaitu memberi kesempatan secara terbuka kepada semua pihak untuk menyampaikan pendapat 
secara merdeka. Kelima, al-Mu'awanah yaitu berkerjasama dan saling menolong. (Nasaruddin Umar, 2019: 12-14)

\section{Tawaran Solusi}

Munculnya sikap radikal dan ekstrim dalam beragama dikalangan milenial tak lepas dari berbagai faktor. Walaupun media sosial dan internet ditenggarai menjadi faktor penyebab bagi penyebaran faham radikalisme tapi ada faktor-faktor lain yang menjadi latar belakang, pengaruh tersebut dengan mudah masuk ke dalam alam fikiran kaum milenial. Sehingga, solusi yang ditawarkan tidak semata berbasis media sosial dan internet seperti pengontrolan terhadap perilaku pengguna dan pembrendelan situs-situs radikal.

Pertama adalah potensi radikalisme yang memang terdapat di setiap agama. Setiap agama, secara teologi mengakui kebenaran subjektif-nya masingmasing. Akan tetapi kebenaran subjektif yang banyak tersebut kemudian memasuki ruang objektif dan mengakibatkan pergesekan serta konflik klaim kebenaran. Pemerintah sebagai pemegang kebijakan harus bersikap adil dalam melihat polemik klaim kebenaran agama. Pemerintah harus menjadi mercusuar bagi kampanye kebebasan beragama dan berkeyakinan. Masyarakat-pun harus menjadi pelopor gerakan toleransi dan saling menghormati keyakinan beragama.

Kedua, radikalisme memiliki akar historis sampai ke sejarah pembentukan negara. Jika merujuk kepada referensi-referensi utama, perdebatan mengenai bentuk negara secara berkesinambungan melahirkan generasi-generasi yang pro negara Islam dan menumbuhkembangkan diskursus tersebut dalam ruang-ruang publik. Beberapa pemberontakan seperti DI/TII, terkait erat dengan keinginan beberapa pihak untuk membuat Indonesia menjadi negara agama. Ketidaktuntasan penanganan pemberontakan (lebih kepada militeristik dan mengabaikan persuasif) menciptakan kultur-simpatik di daerah-daerah basis pemberontak yang secara potensial menciptakan jenis radikalisme yang baru.

Solusi persoalan kedua ini haruslah bersifat kognitif dan kritis. Ulama, akademisi dan intelektual harus membangun diskursus moderat dalam tafsirtafsir agama. Harus ada ketuntasan narasi hubungan antara agama dan negara. Bahwa negara Indonesia berdasarkan pancasila dan undang-undang dasar 1945 secara substansi mengambil ruh dan nilai dari kebaikan agama. Dengan demikian, landasan tersebut bukan sesuatu yang bertentangan dengan agama. Para pendiri bangsa, lebih memilih menjadikan Indonesia sebagai Darussalam (dengan cakupan yang lebih luas) daripada Darul Islam. 
Ketiga, adanya keterlambatan dalam penanganan kasus radikalisme. Saat beberapa mahasiswa membaiat diri kedalam afiliasi Hizbut Tahrir Indonesia beberapa tahun lalu, kita kaget dan baru menyadari bahwa mereka telah dibina bertahun-tahun. Disisi lain, moderasi beragama baru menjadi bagian dari proyek strategis negara paling jauh sekitar 10 tahun terakhir. Keterlambatan ini jika tidak diantisipasi secara kreatif tidak akan memberi dampak apa-apa. Milenial yang terpapar radikalisme umumnya telah menutup pikiran mereka dari diskursus diluar pakemnya. Untuk memasuki alam pikiran mereka adalah tantangan yang besar. Oleh karena itu, ulama, akademisi, intelektual dan masyarakat harus berjibaku mensosialisasikan model keberislaman moderat sembari memberi contoh keteladanan yang baik sehingga dapat mengetuk hati dan membuka pikiran milenial yang terpapar radikalisme untuk kembali ke jalan washatan, beragama secara moderat.

Keempat, faktor ketidakadilan, ketimpangan ekonomi dan kemiskinan. Jika kita memperhatikan pola perekrutan dan pendoktrinan Hizbut Tahrir Indonesia, selalu dimulai dari pemaparan mengenai ketidakadilan, ketimpangan ekonomi dan penindasan negara. Betapa negara tidak adil kepada umat Islam. Betapa negara ini hanya menghasilkan pemimpin-pemimpin korup. Atau betapa alat produksi dikuasai oleh orang-orang yang bukan Islam. Doktrin semacam ini tentu efektif untuk mempengaruhi presepsi kaum milenial yang disatu sisi membutuhkan masa depan yang cerah tapi disisi lain dihadapan mereka kehidupan begitu centang perenang dan penuh ketidakpastian. Untuk itu, sudah menjadi tugas negara dan pemangku kepentingan untuk menciptakan proyekproyek stategis berbasis pemulihan ekonomi dan kesejahteraan masyarakat. Karena dalam pengamatan kami, suburnya radikalisme di Indonesia sangat berkait erat dengan persoalan kemiskinan dan ketimpangan ekonomi.

Selain keempat faktor ini, ada banyak sekali faktor lain yang menjadi alat dukung bagi suburnya faham radikalisme di Indonesia. Untuk itu, diharapkan kepada ulama, intelektual dan akademisi untuk bahu membahu, membangun tafsir agama yang moderat sembari mengupayakan rekomendasi-rekomendasi langkah strategis perbaikan ekonomi dan kesejahteraan masyarakat.

\section{KESIMPULAN}

Secara kultural, moderasi beragama sejatinya telah dipraktekkan oleh masyarakat Indonesia. Namun ada kecenderungan penguatan dan radikalisasi beragama yang merusak semangat moderasi tersebut. Hal ini dapat memicu perpecahan dan membawa kemunduran bagi pembangunan manusia Indonesia 
disegala aspek (sosial, politik dan ekonomi). Untuk itu, pemerintah berserta masyarakat bersama-sama merekonstruksi dan menumbuh kembangkan kembali semangat moderasi.

Pada tahun 2018 dan 2020, survey beberapa lembaga menemukan bahwa setengah dari penduduk Indonesia berusia antara 14 sampai 35 tahun. Artinya, saat ini Indonesia mengalami surplus generasi potensial yang akan berkontribusi bagi pembangunan Indonesia di 10, 20 sampai 30 tahun ke depan. Namun persoalannya kemudian, mayoritas generasi muda tersebut ditenggarai dekat dengan indoktrinasi dan radikalisme beragama karena pengaruh informasi dari internet dan media sosial. Akibatnya akan sangat membahayakan bagi semangat kebersamaan dan toleransi di tahun-tahun mendatang.

Ada 4 indikator moderasi beragama yang ditetapkan oleh Pemerintah yaitu komitmen kebangsaan, toleransi, anti-kekerasan dan penerimaan terhadap tradisi. Indikator tersebut diambil dari faktra lapangan bahwa tindakan-tindakan ekstrim beragama sering berangkat dari beberapa hal tersebut. Umumnya, isuisu radikalisme berkaitan dengan penolakan terhadap negara bangsa (nation state), intoleransi karena klaim kebenaran (truth claim), kekerasan atas nama jihad dan nahi munkar (violence) dan penolakan terhadap tradisi lokal (rejection).

Kenyataannya, sulit untuk mengubah pola fikir hasil indoktrinasi kecuali subjek yang bersangkutan mau membuka pikiran. Tanpa penanganan yang tepat, proses deradikalisasi justru akan menimbulkan radikalisme yang baru. Penanganan isu radikalisme dengan cara-cara frontal dikhawatirkan akan memunculkan gerakan radikal yang lebih baru, lebih luas dan lebih mendalam. Cepat atau lambat, jika generasi muda tidak diberikan wawasan moderasi beragama, perpecahan dan perang saudara akan terjadi. Dan hal ini tentu tidak bisa dibiarkan terjadi.

Untuk itu perlu melihat aspek-aspek terkait radikalisme secara utuh. Tulisan ini merangkum setidaknya 4 aspek terkait radikalisme yang perlu diperhatikan dalam upaya moderasi beragama yaitu aspek potensi radikalisme yang terdapat dalam setiap agama, polemik historis hubungan agama dan negara, keterlambatan merespon gerakan radikal transnasional dan ketidakadilan serta ketimpangan ekonomi. Dibutuhkan sinergisitas antara ulama, intelektual, akademisi, tokoh masyarakat, pelaku usaha dan masyarakat serta pemerintah dalam upaya komprehensif menyuarakan moderasi beragama dan menolak radikalisme khususnya dikalangan milenial. 


\section{DAFTAR PUSTAKA}

Burrel, Gibson dan Gareth Morgan. (2005). Sociological Paradigms and Organization Analysis; Elements of The Sociology of Coorporate Life, Ashagate, Limiter England.

Bustamam-Ahmad, K. (2019). The Religious Imagination in Literary Network and Muslim Contestation in Nusantara. Jurnal Ilmiah Peuradeun, 7(2), 217244. doi:10.26811/peuradeun.v7i2.344

Dirjen Pendis. (2021). Keputusan Direktur Jenderal Pendidikan Islam Nomor 897 Tahun 2021 Tentang Petunjuk Teknis Rumah Moderasi Beragama, Kementerian Agama Republik Indonesia, Jakarta.

https://nasional.tempo.co/read/1029658/kampus-ini-teliti-radikalisme-di-internethasilnya/full\&view $=0 k$ (diakses 20 April 2021)

Ilyas, M., Ismail, Z., Abdullah, M., \& Zulfidar, F. (2020). Youth Existence and Radicalism in Aceh, Indonesia. Jurnal Ilmiah Peuradeun, 8(2), 409-422. doi:10.26811/peuradeun.v8i2.431

Irawan, Aditya Wicaksono, dkk. (2020). Laporan Survey Internet Asosiasi Pengguna Jasa Internet Indonesia 2019 - 2020 (Q2), APJII, Jakarta

John L. Espino et.al, (ed). (2008). Asian Islam in the 21 ${ }^{\text {st }}$ Century, Oxford University Press.

Muhtarom, Ali. (2020). Moderasi Beragama, Konsep, Nilai dan Strategi Pengembangan di Pesantren, Yayasan Talibun Nusantara, Jakarta.

Shihab, M. Quraisy. (2019). Wawasan Islam tentang Moderasi Beragama, Lentera Hati, Jakarta.

Suharto, Babun, et.al. (2019). Moderasi Beragama dari Indonesia untuk Dunia, Lkis, Yogyakarta.

Suseno, Franz Magnis, et.al. (2015). Agama, Keterbukaan dan Demokrasi; Harapan dan Tantangan, Pusat Studi Agama dan Demokrasi Yayasan Paramadina, Jakarta. 
Tim Penyusun Kementerian Agama RI. (2019). Moderasi Beragama, Badan Litbang dan Diklat Kementerian Agama RI, Jakarta.

Umar, Nasaruddin. (2019). Islam Nusantara; Jalan Panjang Moderasi Beragama di Indonesia, Elex Media Komputindo, Jakarta.

Zaprulkhan. (2020). Rekonstruksi Paradigma Maqashid Asy-Syari'ah; Kajian Kritis dan Komprehensif, Ircisod, Yogyakarta. 